\author{
Grzegorz Godlewski \\ https://orcid.org/0000-0002-5860-1795 \\ Uniwersytet im. Adama Mickiewicza w Poznaniu \\ Wydział Nauk Geograficznych i Geologicznych \\ Katedra Turystyki i Rekreacji \\ godlewskig@wp.pl

\section{KONTROWERSYJNE RODZAJE PODRÓŻY W OPINIACH POLSKICH PRODUCENTÓW TURYSTYCZNYCH: TURYSTYKA DOŚWIADCZEŃ}

\begin{abstract}
Abstrakt: Celem badań była diagnoza rynkowych możliwości rozwoju kontrowersyjnych form turystyki w Polsce w ujęciu podażowym, opartym na opiniach i dostępnej ofercie produktów u touroperatorów i detalicznych agentów podróży. Dane analityczne zgromadzono, wykorzystując metody: desk research oraz CATI $(\mathrm{N}=107)$. Wśród najbardziej kontrowersyjnych form podróżowania na pierwszym miejscu zdecydowanie stawiano turystykę narkotykową i seksturystykę, na kolejnych pozycjach zaś - turystykę katastrof, turystykę medyczną, slumsową, fanoturystykę i turystykę ubóstwa. Oczekiwania ofertowe klientów wiążą się najczęściej z turystyką zabawy i podróżami ekstremalnymi, a producenci podkreślają, że omawiany segment rynku będzie się systematycznie rozwijał.
\end{abstract}

Słowa kluczowe: kontrowersje na rynku podróży, turystyka doświadczeń.

\section{WSTĘP}

Artykuł został poświęcony jednemu z najbardziej złożonych problemów pojawiających się w sektorze turystycznym. Jego skomplikowany charakter odnosi się nie tylko do kwestii poznawczych, wynikających z procedury gromadzenia danych poddawanych następnie naukowej analizie i interpretacji, ale przede wszystkim do wielości czynników, które mają wpływ na konsumpcję oferty turystycznej. Z oczywistych względów tematu tego nie da się wyczerpać $\mathrm{w}$ jednej tylko publikacji czasopiśmienniczej.

W przestrzeni naukowej w Polsce istnieją już próby badawcze i publikacje wpisujące się w ramy tzw. turystyki kontrowersyjnej. Zwykle jednak są skoncentrowane na wybranych rodzajach turystyki, rzadko zaś na ich kompilacji, tymczasem to właśnie ona pozwala na uzyskanie względnie pełnego obrazu procesów potrzebnych do oceny szans rozwojowych określonego segmentu rynku. Braki w dostępnej literaturze, uniemożliwiające prowadzenie pogłębionej merytorycznej dyskusji, potwierdzają ponadprzeciętny potencjał badawczy obejmujący kontrowersyjne formy podróży, zwłaszcza w kontekście korelowania zjawisk turystycznych $\mathrm{z}$ dysfunkcyjnymi zachowaniami człowieka i zagadnieniami etycznymi.
Celem autora artykułu było zdiagnozowanie rynkowych możliwości rozwoju kontrowersyjnych form turystyki w Polsce na podstawie opinii producentów - organizatorów turystyki i detalicznych agentów podróży.

Szczegółowe cele badawcze dotyczyły:

1. Identyfikacji znajomości potrzeb klientów w kontekście częstotliwości ich zapytań odnoszących się do tej kategorii ofert turystycznych.

2. Próby odpowiedzi na pytanie, czy sektor turystyki zmierza w kierunku traktowania kontrowersyjnych form działalności jako jego istotnego elementu składowego.

W pracy przyjęto także założenie, że ten segment rynku turystycznego jest powiązany z doświadczeniami, których współcześni konsumenci poszukują w kontakcie z dysfunkcyjnymi rodzajami podróży.

\section{DOŚWIADCZENIA W TURYSTYCE}

Gospodarka doświadczeń (ekonomia doświadczeń) sięga korzeniami do USA końca XX w. i odwołuje się do portretu współczesnego konsumenta, kierującego się 
emocjami przy podejmowaniu wyborów zakupowych (Kacprzak, Dziewanowska, Skorek, 2015; Stasiak, 2013). W 1992 r. niemiecki socjolog Schulze opisał ideę społeczeństwa doświadczającego (Erlebnisgesellschaft), a w 1998 r. Pine oraz Gilmore (1998) posłużyli się sformułowaniem experience economy, które przyjęło się $\mathrm{w}$ dyskursie naukowym.

Czynnikiem warunkującym powstawanie doświadczeń jest obecność człowieka (jego zasób wiedzy, wrażliwość) oraz obecność surowców, towarów i usług. Niemniej jednak to doświadczenia stanowią warunek wymiany rynkowej, ponieważ klienci, podejmując decyzje zakupowe, oceniają szanse na uzyskanie dzięki konsumpcji oczekiwanych wrażeń (głównie pozytywnych). Silnym bodźcem rozwojowym dla gospodarki doświadczeń staje się także kultura, podlegająca procesowi karnawalizacji - konsumenci przytłoczeni nadmiarem produktów materialnych poszukują nowych stymulantów. Zaczyna to przypominać samonapędzający się mechanizm karuzelowy, a zadaniem oferentów staje się kreowanie i dostarczanie zabawy i rozrywki (Barber, 2008; Bauman, 2007).

Sektor turystyki jest silnie skorelowany z czasowymi zmianami, które zachodzą w życiu wyjeżdżającego. Podróż dostarcza nowych bodźców i wrażeń związanych z miejscami, ludźmi, produktami. Kwestia doświadczenia w turystyce często opiera się na uwzględnieniu autentyczności atrakcji i towarzyszących jej doznań. Koncepcję tę zainicjował MacCannell $(1973,1976)$ niemal pięć dekad temu, ale na rynku publikacyjnym pojawiają się także nowe badania obejmujące ten zakres tematyczny (zob. np. Åstrøm, 2017; Sigala, 2016; Weisheng, Ho, 2017; Zatori, Beardsley, 2017).

Specjaliści przyznają, że turystyka jest istotną częścią sektora sprzedaży doświadczeń (Ooi, 2002; Prentice, Witt, Hamer, 1998) zakotwiczonych w ludzkich zachowaniach, odczuwanych bardzo osobiście i podlegających ekspresji. Owe wieloaspektowe doświadczenia zostają opisane zarówno w kontekstach środowiskowych, jak i społecznych (Abrahams, 1986).

Doświadczenia turystyczne w różnych społeczeństwach nie są odzwierciedlane $\mathrm{w}$ ten sam sposób. Złożoność rozumienia ich istoty opisywano w literaturze (Lee, Shafer, 2002). Pojawiły się także metody służące ich rozróżnianiu. Badacze koncentrowali się początkowo na psychologii kognitywnej (Lee, Shafer, 2002; Stamboulis, Skayannis, 2003), powiązanej z procesami postrzegania doświadczeń przez turystów (Waitt, 2000; Waller, Lea, 1999). Te wyobrażenia i oczekiwania mają decydujący wpływ na sposoby konsumpcji i oceny produktu turystycznego. Autorzy innych publikacji twierdzą, że aktywność turystyczna umożliwia zdobywanie doświadczeń, szczególnie postrzeganych jako najkorzystniejsze dla jednostki. Mogą one dotyczyć poprawy samopoczucia, stwarzać szansę na wyrażenie siebie, a także pozwolić na pogłębioną kontemplację odwiedzanych miejsc i kul- tur (Lee, Shafer, 2002; Prentice, Witt, Hamer, 1998). Dążenie do konsumpcji doświadczeń turystycznych staje się środkiem do osiągnięcia tego celu (Ooi, 2003).

Empiryczne, głębokie doznania, pojawiające się w przypadku doświadczeń optymalnych, to rodzaj stanu psychicznego, który jest opisywany przez turystów jako wyjątkowy (Ellis, 1994; Walker, Hull, Roggenbuck, 1998). Ten rodzaj doświadczeń silnie angażuje, okazuje się emocjonalnie intensywny, niekiedy wręcz transcendentny (Csíkszentmihályi, 1993).

Za sprawą doświadczeń turystycznych można zauważyć różnice między mieszkańcami odwiedzanych regionów a turystami. Urry (1990) podkreśla, że turyści doświadczają miejsc, zauważając rzeczy, których nie dostrzegają w codziennym otoczeniu. Nie mają oni wystarczającej wiedzy o regionie, aby postrzegać rzeczywistość w taki sam sposób jak autochtoni. Na prawdziwy obraz miejsca turyści patrzą przez pryzmat własnych środowisk (Ooi, 2002). Odwiedzający mogą zatem jedynie w przybliżony sposób poznać lokalną kulturę, do której mają ograniczony dostęp (Hannabuss, 1999; Ooi, 2002).

Motywacje podróżnicze - silnie rozbudowane - coraz częściej determinują tworzenie nowych typologii podróży. Początki tych klasyfikacji wydają się korelować z tradycjami. Arnould i Price (1993), analizując zachowania uczestników spływów rzekami, wyznaczyli takie oto wymiary doświadczeń: harmonijną łączność z naturą, poczucie wspólnoty, osobisty rozwój i odnowę.

$\mathrm{W}$ analizie sektora usług turystycznych badacze wyróżniają też inne, bardzie złożone typologie. Jedną z nich, sześciostopniową, zaproponowali Otto i Ritchie (1996). Hedonizm, interaktywność, nowość/oryginalność, komfort, bezpieczeństwo i stymulacja tworzą silną kompilację doświadczeń $w$ turystyce. Nie można się z tym nie zgodzić, w każdym niemal rodzaju podróży przewija się bowiem ta różnorodność, akcentowana silniej lub słabiej, w zależności od kategorii odbiorcy i założeń producenta. Do wymienionego powyżej zestawu cech Rageh, Melewar i Woodside (2013) dołączają także kilka kolejnych: wymiar edukacyjny, relacyjny, uznanie i piękno, które idealnie wpasowują się np. w turystykę krajoznawczą, kwalifikowaną czy aktywną, podobnie zresztą jak doświadczenia odnoszące się do osobistych odczuć, nowości/oryginalności, zaskoczenia, uczenia się i zaangażowania, proponowane przez Poulssona i Kale (2004).

Ciekawa okazała się koncepcja teatralna, zgodnie z którą dostarczanie bodźców wywołuje określone emocje wśród odbiorców. Polega ona na zaadaptowaniu wybranych elementów teatralnej metafory do praktyki biznesowej i zainicjowaniu projektu na podobieństwo rzeczywistego przedstawienia teatralnego. Mechanizmy te są właściwe dla kontemplowania sztuki - produkty i usługi mają zwykle charakter przejściowy (podobnie jak przedstawienie) i wywołują określone emocje w relacjach międzyludzkich (w teatrze także zauważalne). 
Zakres wykorzystywania tej metafory jest bardzo szeroki, jest ona bowiem używana w odniesieniu do handlu detalicznego (Deighton, 1999; Goodwin, 1996; Harris, Harris, Baron, 2003), ochrony zdrowia czy funkcjonowania wyższych uczelni (John, 1996; Williams, Anderson, 2005).

Badanie rynku podróży przez pryzmat gospodarki doświadczeń wiąże się m.in. ze wskazywaniem nowych destynacji oraz kreowaniem produktów turystycznych. Obszarem zainteresowań badawczych, w który wpisuje się niniejszy artykuł, jest turystyka wraz z bogatym spektrum form, szczególnie tych, które powszechnie uważa się za dyskusyjne czy kontrowersyjne. Ich istota, choć zgodna z założeniami terminologicznymi turystyki, w wyrazie społecznym budzi wiele wątpliwości - także w odniesieniu do aspektów ekonomicznych.

\section{KONTROWERSYJNOŚĆ TURYSTYKI}

Kopaliński (2014) wyjaśnia, że słowo „kontrowersja” oznacza 'wątpliwość, sprzeczkę, spór', a w Stowniku języka polskiego PWN zostało ono zdefiniowane jako różnica zdań prowadząca do dyskusji i sporów (Słownik języka polskiego, 2018). Inny leksykograf dodaje, że słowa "kontrowersyjne" używamy wtedy, gdy wyrażamy swoją negatywną opinię na dany temat (Bańko, 2000, s. 675).

Pomimo definicyjnych wątpliwości, które ten rodzaj podróży wzbudza wśród specjalistów sektora turystycznego i naukowców, można próbować charakteryzować turystykę kontrowersyjną jako działalność wywołującą kontrowersje, prowokującą do dyskusji i najczęściej prezentowaną w negatywnym świetle (Stasiak, 2015). Lubowiecki-Vikuk i Paczyńska-Jędrycka (2010) zawężają ów termin do działań o zdecydowanie negatywnym zabarwieniu, stojących w konflikcie z prawem (turystyka aborcyjna, eutanazyjna, narkotykowa). W literaturze uwidacznia się także szersza perspektywa rozumienia kontrowersyjności w sektorze podróży (Moufakkir, Burns, 2012).

Stasiak (2015) wyróżnia pięć głównych obszarów, które wywołują dyskusje i spory: zachowania turystów, miejsca wyjazdu, formy turystyki (zob. tab. 1), produkty turystyczne i efekty turystyczne. Oznacza to, że podróże mogą powodować liczne dysfunkcje o wielowarstwowym charakterze.

Nie ma możliwości bezpośredniego dopasowania kategorii kontrowersji do form turystyki i zachowań turystycznych, które zwykle, podobnie jak w przypadku funkcji turystycznych, nierozerwalnie łączą się ze sobą, a każda próba ich systematyzacji skazana jest na uzasadnioną krytykę. Podstawowym wyróżnikiem turystyki kontrowersyjnej są motywy jej uprawiania, szczególnie z perspektywy segmentów rynku turystycznego. Panasiuk (2015) klasyfikuje je jako potencjalnie kontrowersyjne, umiarkowanie kontrowersyjne i powszechnie uważane za kontrowersyjne. Granica między poszczególnymi klasami jest jednak subiektywna.

Struktura podaży rynku turystycznego związanego z podróżami kontrowersyjnymi wydaje się jeszcze bardziej złożona. Przede wszystkim należy odwoływać się

Tabela 1. Kontrowersyjne formy turystyki

\begin{tabular}{|c|l|l|}
\hline Lp. & \multicolumn{1}{|c|}{$\begin{array}{c}\text { Formy } \\
\text { turystyki }\end{array}$} & \multicolumn{1}{c|}{ Kontrowersje wokół zjawiska } \\
\hline 1 & Turystyka aborcyjna & $\begin{array}{c}- \text { dokonywanie zabiegów aborcji bez względu na wskazania medyczne w państwach o liberalnym } \\
\text { systemie prawnym }\end{array}$ \\
\hline 2 & Turystyka eutanazyjna & - poddawanie się zabiegom wspomaganej śmierci \\
\hline 3 & Turystyka narkotykowa & - dokonywanie transakcji kupna/sprzedaży środków odurzających lub wyjazdy w celu ich zażywania \\
\hline 4 & Turystyka ubóstwa & $\begin{array}{l}- \text { wykorzystywanie trudnej sytuacji ekonomicznej społeczności w państwach słabo rozwiniętych od- } \\
\text { wiedzanych przez turystów }\end{array}$ \\
\hline 5 & Turystyka slumsowa & $\begin{array}{c}\text { - wykorzystywanie trudnej sytuacji ekonomicznej i mieszkaniowej społeczności żyjących w dzielni- } \\
\text { cach biedy w dużych aglomeracjach miejskich }\end{array}$ \\
\hline 6 & Turystyka ekstremalna & $\begin{array}{c}- \text { przejawianie zachowań skrajnie ekstremalnych, zagrażających życiu i zdrowiu turystów, podej- } \\
\text { mowanie nieuzasadnionego ryzyka }\end{array}$ \\
\hline 7 & Turystyka katastrof & $\begin{array}{c}- \text { ryzykowne zachowania w miejscach katastrof naturalnych lub spowodowanych przez człowieka; } \\
\text { wkraczanie na tereny lub do obiektów, które nie są udostępnione zwiedzającym }\end{array}$ \\
\hline 8 & Turystyka seksualna & $\begin{array}{c}- \text { nawiązywanie relacji seksualnych prawnie zakazanych w kraju pochodzenia turysty; wykorzysty- } \\
\text { wanie osób nieletnich oraz kobiet w przemyśle seksturystycznym }\end{array}$ \\
\hline 9 & Turystyka zabawy & $\begin{array}{c}- \text { nadmierna konsumpcja używek i alkoholu, prowadząca często do przekraczania norm etycznych, } \\
\text { kulturowych i prawnych w miejscach recepcji }\end{array}$ \\
\hline 10 & $\begin{array}{l}\text { Turystyka wieczorów } \\
\text { kawalerskich/panieńskich }\end{array}$ & $\begin{array}{c}- \text { konsumpcja środków odurzających, alkoholu, a także korzystanie z usług seksualnych/erotycznych } \\
\text { w odwiedzanych miejscach }\end{array}$ \\
\hline 11 & Tanatoturystyka & $\begin{array}{c}- \text { nadmierne skomercjalizowanie miejsc śmierci; łączenie sfery sacrum i profanum przez odwiedzają- } \\
\text { cych }\end{array}$ \\
\hline 12 & Fanoturystyka & - brutalizacja zjawiska kibicowania; „ustawki” pseudokibiców; wandalizm i niszczenie mienia \\
\hline
\end{tabular}

Źródło: opracowanie własne na podstawie Stasiak (2015, s. 53-69). 
do ofert turystycznych tworzonych przez przedsiębiorców turystycznych, mających na celu wpływanie na motywacje i zachowania turystów. W odniesieniu do produktu turystycznego można rozważyć następujące kontrowersje: cząstkowe usługi turystyczne (np. niskiej jakości), niekompletne pakiety turystyczne (bez obowiązkowego ubezpieczenia lub sprzedawane po stosunkowo niskich cenach, oferowane $w$ nieodpowiednim czasie - poza sezonem), ceny (wyraźnie zawyżone lub znacznie zaniżone $\mathrm{w}$ porównaniu $\mathrm{z}$ ofertami konkurencji) oraz parametry jakościowe oferty (Panasiuk, 2015). Inne kontrowersyjne aspekty mogą dotyczyć walorów turystycznych zarówno przyrodniczych, jak i kulturowych, atrakcji turystycznych, elementów infrastruktury turystycznej, usług turystycznych, kompleksowości ofert w miejscach recepcji, działań marketingowych czy aspektów wizerunkowych turystyki (Panasiuk, 2015).

Na zakończenie warto wspomnieć o kontrowersjach ekonomicznych, jakie wzbudza współczesna turystyka. Ich przykładami są: gospodarczy wyzysk krajów biednych, o słabej gospodarce, przez międzynarodowy przemysł turystyczny; neokolonializm turystyczny, przejawiający się m.in. budową "gett turystycznych"; a także transferowanie zysków z inwestycji niemal w całości za granicę, co w kontekście dużej skali tego zjawiska prowadzi do powstania tzw. monokultury turystycznej. Załamanie koniunktury (ograniczenie turystyki przyjazdowej) może prowadzić do destabilizacji gospodarki i jeszcze głębszego uzależnienia ekonomicznego kraju (Jasiński, 2006).

Badacze zajmują różne stanowiska w kwestii obarczania winą za rozwój kontrowersyjnych rodzajów turystyki (Podemski, 2013). Odwiedzający w swoich poszukiwaniach często padają ofiarą przemysłu turystycznego (MacCannell, 2002), sami do tego doprowadzając, wskutek domagania się produktów wpisujących się w ten rodzaj turystyki. Trzeba pamiętać, że poszukiwanie krańcowych doświadczeń i doznań $\mathrm{w}$ aktywności turystycznej nierzadko prowadzi do świadomych zagrożeń dla zdrowia, życia człowieka oraz przyrody czy kultury.

\section{METODYKA BADAŃ}

Artykuł został poświęcony problematyce kontrowersji pojawiających się na polskim rynku turystycznym, które - jak dotąd - nie były poddawane wyczerpującym analizom naukowym i nie zostały wystarczająco potwierdzone publikacjami. Jednocześnie badania te mogą być wskazówką dla sektora turystycznego - pokazują tendencję zmian na rynku turystycznym.

Materiał badawczy zebrano przy użyciu dwóch metod:

- desk research, czyli analizy materiałów zastanych (tzw. wirtualnej etnografii), pozwalającej wstępnie zdiagnozować podażową stronę rynku turystycznego zajmującego się m.in. kontrowersyjnymi ofertami turystycznymi;

- wywiadu telefonicznego wspomaganego komputerem (CATI - The Computer Assisted Telephone Interview).

W przypadku organizatorów turystyki kontakt telefoniczny jest (obok mailingu) naturalną metodą komunikacji z klientami. Ponadto rozmowa telefoniczna, pomimo ustrukturyzowanego charakteru wynikającego z zastosowania kwestionariusza wywiadu, w przypadku trudnych i kontrowersyjnych zagadnień czy niejasnych pytań, dawała ankieterowi możliwość udzielenia pomocy i dodatkowych wyjaśnień, jeśli zaszła taka potrzeba. Czytał on pytania i przetwarzał otrzymane odpowiedzi, wykorzystując specjalny skrypt komputerowy, umożliwiający automatyczne skalowanie danych i tworzenie niezbędnych statystyk. Scenariusz badania CATI składał się z siedmiu pytań głównych, a odpowiedzi pogłębiano pytaniami warunkowymi (filtrującymi). Średni czas trwania jednego wywiadu nie przekraczał czterech minut.

Wywiady przeprowadzono z przedstawicielami 107 firm turystycznych. Wśród struktury badanych przedsiębiorstw wyróżniono: organizatorów podróży $(67 \%)$, agentów turystycznych $(20 \%)$, pośredników turystycznych $(8 \%)$ oraz inne podmioty, w tym stowarzyszenia turystyczne $(5 \%)$.

Podczas realizacji badań skorzystano z usług firmy zajmującej się analizą rynku. Dane wykorzystane do przygotowania artykułu były częścią szerszego projektu badawczego realizowanego przez autora w latach 2016 2019, obejmującego kontrowersje na rynku turystycznym w Polsce.

\section{ANALIZA WYNIKÓW BADAŃ}

Pierwszym elementem analizy materiału badawczego była ocena zmian, które zaszły w ciągu ostatnich pięciu lat $w$ Polsce, $w$ oczekiwaniach klientów odnośnie do proponowanych ofert turystycznych. Zdecydowana większość badanych firm deklarowała zmiany zauważalne (77\%). Największy odsetek odpowiedzi twierdzących pojawił się u agentów będących pośrednikami i mających w swoim asortymencie wiele zróżnicowanych ofert turystycznych. W opinii tej grupy oczekiwania klientów systematycznie rosną i dotyczą najczęściej trzech czynników: wyższego standardu oferty, korzystniejszej ceny oraz bezpieczeństwa. $W$ dalszej kolejności objęte badaniem podmioty wymieniły wyższą jakość usług oraz nowe destynacje, które mogłyby stać się interesujące dla odwiedzających.

Wymienione aspekty silnie korespondują z rozumieniem pojęcia "turystyka kontrowersyjna”, o którą także zapytano przedstawicieli przedsiębiorców. Mianem wy- 
jazdów kontrowersyjnych określali oni podróże związane $\mathrm{z}$ brakiem bezpieczeństwa i jednocześnie niebezpiecznymi kierunkami (miejsca zagrożone terroryzmem, konfliktami, wojną), seksturystykę czy turystykę ekstremalną. Autor stworzył zestawienie rodzajów turystyki najbliższych kontrowersyjnym formom podróżowania i poprosił o ich ocenę przedstawicieli organizatorów wyjazdów przy zastosowaniu skali od 1 do 10, gdzie 1 oznaczało „w ogóle nie jest kontrowersyjne”, a 10 - „bardzo kontrowersyjne".

Respondenci określili turystykę narkotykową jako najbardziej kontrowersyjną. Jako drugą w kolejności ankietowani wymieniali seksturystykę, a następnie - turystykę katastrof, turystykę medyczną, slumsową, fanoturystykę i turystykę ubóstwa, które zaliczyli do produktów średnio kontrowersyjnych. Mało kontrowersyjne, zdaniem badanych, były tanatoturystyka, ekstremalne formy podróży oraz wyjazdy o zabarwieniu hedonistycznym (clubbing, wieczory panieńskie/kawalerskie) (rys. 1). Aby lepiej zobrazować problem, skumulowano wartości dla wskazań najwyższych $-8,9,10$, co pozwoliło na precyzyjne określenie odsetka osób, które uzyskały ten zakres wyników (tzw. procent skumulowany) (rys. 2).

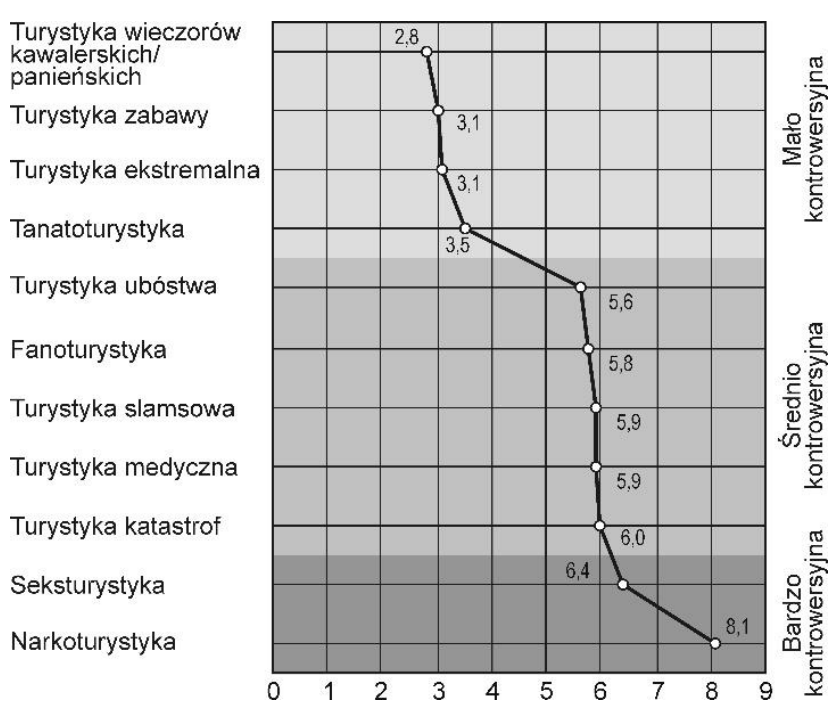

Rysunek 1. Stopień kontrowersyjności rodzajów turystyki $\mathrm{w}$ ocenie badanych organizatorów podróży

Źródło: badania własne

Częstotliwość zapytań i oczekiwań ofertowych klientów w dziedzinie kontrowersyjnych form podróży (w skali od 1 do 10, gdzie 1 oznacza „w ogóle się z tym nie spotkaliśmy”, a 10 - „bardzo często się z tym spotykamy") jest odmienna od ocen uzyskanych w poprzednim zestawieniu. $Z$ odpowiedzi osób biorących udział w ankiecie wynika, że w tym przypadku najczęściej (choć - mimo wszystko - sporadycznie) pojawiające się zapytania odnoszą się do turystyki zabawy i podróży ekstremalnych. $W$ dalszej zaś kolejności - turystyki wieczorów kawalerskich/panieńskich, tanatoturystyki i fanoturystyki (rys. 3).



Rysunek 2. Stopień kontrowersyjności rodzajów turystyki - skumulowane wartości najwyższych wskazań Źródło: badania własne

Turystyka zabawy

Turystyka ekstremalna Turystyka wieczorów kawalerskich/ panieńskich

Tanatoturystyka

Fanoturystyka

Turystyka medyczna

Turystyka katastrof

Seksturystyka

Turystyka ubóstwa

Turystyka slamsowa

Narkoturystyka

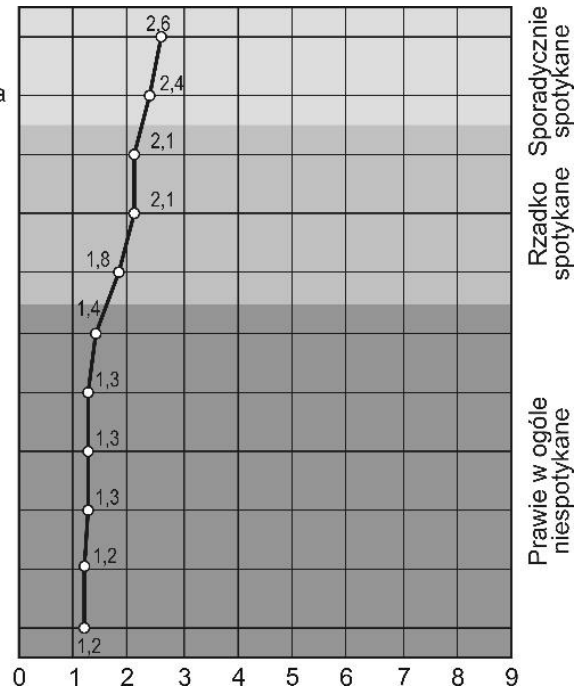

Rysunek 3. Częstotliwość zapytań klientów o kontrowersyjne formy podróży

Źródło: badania własne

W ocenie respondentów zainteresowanie klientów formami turystyki kontrowersyjnej wzrośnie w najbliższych latach. Za takim kierunkiem ewentualnych zmian na rynku podróży opowiedziało się niemal 3/4 przedsiębiorców, z tym że touroperatorzy (74\%) są bardziej przekonani o tym fakcie niż agenci turystyczni $(57 \%)$ (rys. 4).

Ankietowanych zapytano również, czy ich zdaniem sektor turystyczny będzie ewoluować w Polsce w kierunku traktowania kontrowersyjnych form aktywności turystycznej jako powszechnego elementu dostępnej na rynku oferty. Ponad połowa przedstawicieli firm uważa, że tak. Przy bardziej szczegółowej analizie wartości skumulowanych $8 \%$ przedstawicieli przedsiębiorców było „zdecydowanie na tak”, 16\% - na "tak”, a 32\% 

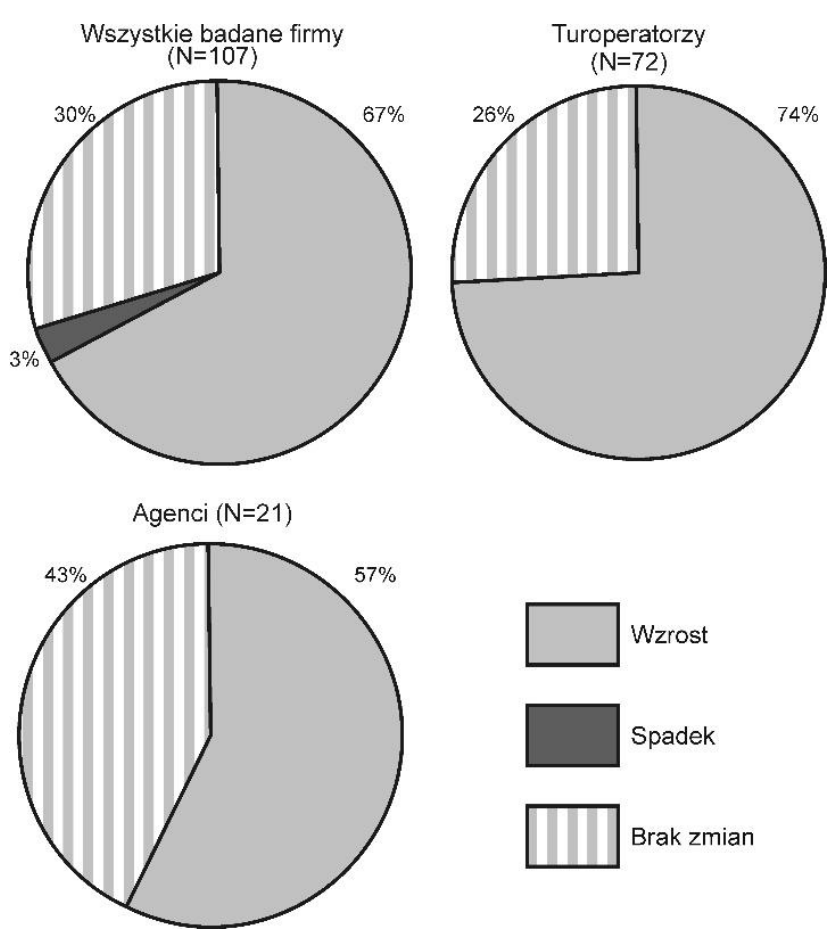

Rysunek 4. Stopień zainteresowania ofertą turystyki kontrowersyjnej w przyszłości Źródło: badania własne

uznało, że „raczej tak”. Przeciwne zdanie wyraziło sumarycznie $32 \%$ badanych, przy czym: $2 \%$ respondentów odpowiedziało: „zdecydowanie nie”, 8\% - „nie”, a $22 \%$ - „raczej nie".

\section{DYSKUSJA}

Na podstawie wyników przeprowadzonych badań można stwierdzić, że przedstawiciele producentów turystycznych w Polsce mają świadomość kontrowersji pojawiających się w sektorze podróży. Ich zdaniem jest to rynek rozwojowy, choć jeszcze nierozwinięty. Autor ma jednak świadomość, że przeprowadzenie pogłębionej dyskusji nad osiągniętymi rezultatami będzie wyzwaniem. Trudno znaleźć w polskich czasopismach branżowych odpowiednie analizy porównawcze dotykające merytorycznie tej materii. Dlatego też dyskurs na ten temat nie przyjmie formuły komparatywnej, lecz raczej będzie próbą krytycznego spojrzenia na zjawisko w ogóle.

Fakt, że istnieją na rynku produkty społecznie nieakceptowane, a stosunkowo tanie i łatwo dostępne, których produkcji i dystrybucji zakazuje polskie prawo, świadczy o sile mechanizmów rynkowych. Odpowiadają one także rodzajowości niektórych form turystyki (narkoturystyki, seksturystyki, turystyki zabawy), szczególnie gdy mamy do czynienia $\mathrm{z}$ oferowaniem produktów pozbawiających człowieka wolności i władzy nad własnymi decyzjami zakupowymi - konsumentami zostają osoby uzależnione od alkoholu, seksu czy narkotyków. Potwierdza to tezę, że na rynku zostanie wytworzony każdy produkt, bez względu na społeczne koszty i negatywne konsekwencje jego użycia.

Czy zatem jesteśmy w stanie powstrzymywać mechanizmy kierujące rynkowymi zależnościami w turystyce, odnoszące się do zachowań określanych w literaturze jako dewiacyjne? Odpowiedź na tak postawione pytanie $\mathrm{z}$ pewnością nie może być jednoznaczna. W rozmowie $\mathrm{z}$ jednym $\mathrm{z}$ przedstawicieli świata nauki, podczas spotkania zorganizowanego $\mathrm{w}$ trakcie realizacji badań, można jednak uzyskać tego potwierdzenie:

[...] turystyka kontrowersyjna wzrasta i będzie wzrastać Po pierwsze przez bogacenie się społeczeństw; po drugie - zwiększające się różnice pomiędzy dochodami w krajach biednych i bogatych. [...] turystyka kontrowersyjna (i pieniądz) zgodnie ze starym efektem kaskady przesuwa się od krajów bogatych do krajów biednych.

To ekonomiczne ujęcie należy uzupełnić odwołaniem się do sfery ludzkiej psychiki, która opierając się na procesach psychologicznych, prowokuje rozwój oferty turystyki doświadczeń, także w jej kontrowersyjnych przejawach.

Faktem jednak jest, że współczesnych turystów można określić mianem poszukujących, chcących obracać się w sferze niebanalnej, nasyconej autentycznymi emocjami, angażującej zmysły, umożliwiającej osobiste doświadczenie. W związku z tym oryginalność miejsca, zaskoczenie, ekstrawagancja, a nawet różne rodzaje aktywności zwykle uznawane za szokujące stają się elementami podróżniczej codzienności. Czasami wręcz istotniejsze od samej oferty turystycznej okazują się doświadczenia, ekscytacja oraz zadowolenie turysty z pobytu w miejscu docelowym. Powstające w świadomości odwiedzających wrażenia tworzą przestrzeń mentalną, niebędącą wiernym odzwierciedleniem realnego życia i dającą się plastycznie modelować. Ponadto, jak twierdzi Stasiak (2011), zasoby rzeczywistej przestrzeni turystycznej mają fizyczne ograniczenia, a ich doskonalenie może stać się w końcu niemożliwe. Co innego, jeśli mamy na myśli poszerzanie przestrzeni w wymiarze czasowym i mentalnym. Przyszłością rynku turystycznego mogą być zatem nie obszary o wyjątkowych walorach poznawczych, ale te, których odwiedzenie pozwoli turystom wypełnić ów drugi rodzaj przestrzeni.

\section{WNIOSKI}

Badania nad kontrowersyjnością rynku turystycznego w Polsce są jeszcze w fazie wstępnej. W związku z tym wszelkie działania, mogące poszerzyć ich merytorycz- 
ny zakres, wydają się potrzebne i uzasadnione - nie tylko gospodarczo, ale również społecznie. Wypełnienie tej luki poznawczej często bywa ograniczane ze względu na problemy praktyczne $w$ rzetelnej realizacji badań $i$ uzyskiwaniu wiarygodnych wyników. Artykuł ten jest przyczynkiem i wstępnym krokiem do pogłębionej analizy rynku turystycznego, być może także w jego typologicznej formule (zakres potrzeb zaspokajanych w podróży). Pojawianie się nowych kategorii konsumentów pozwala na wyodrębnianie ich i grupowanie, co pociąga za sobą istotne implikacje w marketingu turystycznym.

Kreatywność producentów w zaspokajaniu pojawiających się potrzeb będzie ewoluować. Jej ograniczeniami są jedynie formuły prawne $\mathrm{i}-\mathrm{w}$ niektórych przypadkach - etyczne.

Dalsze badania nad turystyką kontrowersyjną mogą rozszerzać się na różnorodne płaszczyzny - począwszy od analiz sektora podaży turystycznej, jego motywacji i gotowości do obsługi tego specyficznego segmentu, na analizie procesów konsumpcji opartej na dewiacyjnych zachowaniach turystycznych skończywszy. Studia te będą miały formę nie tylko ilościowej analizy sondującej zakres występowania zjawiska, lecz pogłębionych badań jakościowych, dających odpowiedź na pytanie: dlaczego opisywane zjawisko występuje coraz powszechniej i co kryje się za decyzjami zakupowymi klientów? Współcześnie $\mathrm{w}$ badaniach podkreśla się już behawioralny i kognitywistyczny charakter wyborów konsumenckich tego typu.

Silnym paradygmatem w badaniach nad turystyka są analizy, w których uwzględnia się postrzeganie ryzyka w podróży, bezpieczeństwa odwiedzających, przestępczości i terroryzmu, aspektów zdrowotnych, szczególnie chorób, zagrażających turystom w trakcie wyjazdu (Baker, Page, Mayer, 2003; Rittichainuwat, Chakraborty, 2009). Z jednej strony są to czynniki typowo odstraszające, negatywnie wpływające na potencjalne decyzje o wyjeździe, z drugiej - pozwalające na znajdowanie i wdrażanie zapobiegających im rozwiązań. Merytoryczna manipulacja zdarzeniami o tym charakterze może kształtować pozytywne reakcje konsumenckie, $\mathrm{w}$ tym związane z ochroną środowiska naturalnego, kulturowego, ze wsparciem obszarów zagrożonych chorobami, oraz wzbudzać ciekawość i zainteresowanie zarówno ofertą, jak i miejscem.

\section{BIBLIOGRAFIA}

Abrahams, R.D. (1986). Ordinary and extraordinary experience. W: V.W. Turner, E.M. Bruner (red.), The anthropology of experience (s. 45-72). Chicago: University of Illinois Press.

Arnould, E.J., Price, L.L. (1993). River magic: Extraordinary experiences and the extended service encounter. Journal of Consumer Research, 20, 24-45. DOI: https://doi.org/10.1086/209331
Åstrøm, J.K. (2017). Theme factors that drive the tourist customer experience. International Journal of Culture, Tourism and Hospitality Research, 11, 125-141. DOI: https://doi.org/10.1108/ IJCTHR-07-2015-0070

Baker, M., Page, S., Mayer, D. (2003). Urban visitor perceptions of safety during a special event. Journal of Tourism Research, 41 355-361. DOI: https://doi.org/10.1177/0047287503041004004

Bańko, M. (red.) (2000). Inny stownik języka polskiego PWN. Warszawa: Wydawnictwo Naukowe PWN.

Barber, B. (2008). Skonsumowani. Jak rynek psuje dzieci, infantylizuje dorostych i potyka obywateli. Warszawa: Muza.

Bauman, Z. (2007). Konsumenci w społeczeństwie konsumentów. Łódź: Wydawnictwo Uniwersytetu Łódzkiego.

Csíkszentmihályi, M. (1993). The evolving self: A psychology for the third millennium. New York: Harper Collins.

Deighton, J. (1999). The consumption of performance. Journal of Consumer Research, 19, 362-372. DOI: https://doi.org/10.1086/209307

Ellis, G.D.V. (1994). Measurement and analysis issues with explanation of variance in daily experience using the flow model. Journal of Leisure Research, 26, 337-356. DOI: https:/ / doi.org/ 10.1080/00222216.1994.11969966

Goodwin, C. (1996). Moving the drama into the factory: The contribution of metaphors to services research. European Journal of Marketing, 30, 13-36. DOI: https://doi.org/10.1108/ 03090569610130025

Hannabuss, S. (1999). Postmodernism and the heritage experience. Library Management, 20, 295-303. DOI: https:/ / doi.org/ $10.1108 / 01435129910276280$

Harris, R., Harris, K., Baron, S. (2003). Theatrical service experiences: Dramatic script development with employees. International Journal of Service Industry Management, 14, 184-199. DOI: https://doi.org/10.1108/09564230310474156

Jasiński, M. (2006). Aspekty monokulturowe gospodarki turystycznej. Zeszyty Naukowe Kolegium Gospodarki Światowej SGH, 20, 92-102.

John, J. (1996). A dramaturgical view of the health care service encounter: Cultural value-based impression management guidelines for medical professional behaviour. European Journal of Marketing, 30, 60-74. DOI: https://doi.org/10.1108/ 03090569610130043

Kacprzak, A., Dziewanowska, K., Skorek, M. (red.) (2015). Gospodarka doświadczeń. Perspektywa polskiego konsumenta. Warszawa: Wydawnictwo Naukowe PWN.

Lee, B., Shafer, C.S. (2002). The dynamic nature of leisure experience: An application of affect control theory. Journal of Leisure Research, 34, 290-310. DOI: https://doi.org/10.1080/ 00222216.2002.11949973

Lubowiecki-Vikuk, A., Paczyńska-Jędrycka, M. (2010). Wspótczesne tendencje $w$ rozwoju form rekreacyjnych $i$ turystycznych. Poznań: Bogucki Wydawnictwo Naukowe.

MacCannell, D. (1973). Staged authenticity: Arrangements of social space in tourist settings. American Journal of Sociology, 79, 589-603. DOI: https:// doi.org/10.1086/225585

MacCannell, D. (1976). The tourist: A new theory of the leisure class. London: MacMillan

MacCannell, D. (2002). Turysta, nowa teoria klasy próżniaczej. Warszawa: Muza S.A.

Moufakkir, O., Burns, P.M. (2012). Controversies in tourism. Wallingford, OX: CAB International.

Ooi, C.S. (2002). Cultural tourism and tourism cultures: The business of mediating experiences in Copenhagen and Singapore. Copenhagen: Copenhagen Business School Press.

Ooi, C.S. (2003). Crafting Tourism Experiences: Managing the Attention Product. Pobrane z: https://www.researchgate.net/ publication/265987312_Crafting_Tourism_Experiencs_ Managing_the_Attention_Product (11.09.2018). 
Otto, J.E., Ritchie, R.J.B. (1996). The service experience in tourism. Tourism Management, 17, 165-174. DOI: https://doi.org/10. 1016/0261-5177(96)00003-9

Panasiuk, A. (2015). Miejsce turystyki kontrowersyjnej w strukturze rynku turystycznego. W: G. Godlewski, M. Zalech (red.) Turystyka kontrowersyjna na wspótczesnym rynku podróży - formy, uwarunkowania, skutki (s. 7-21). Biała Podlaska: Wydawnictwo AWF.

Pine, B.J., Gilmore, J.H. (1998). Welcome to the experience economy. Boston: Harvard Business Review. Pobrane z: https://hbr.org/ 1998/07/welcome-to-the-experience-economy (10.09.2018).

Podemski, K. (2013). Wyreżyserowana przestrzeń turystyczna. Pobrane z: http://post-turysta.pl/artykul/Wyrezyserowana-przestrzenturystyczna (5.09.2018).

Poulsson, S.H.G., Kale, S.H. (2004). The experience economy and commercial experiences. The Marketing Review, 4, 267-277. DOI: https://doi.org/10.1362/1469347042223445

Prentice, R.C., Witt, S.F., Hamer, C. (1998). Tourism as experience: The case of heritage parks. Annals of Tourism Research, 25, 124. DOI: https:// doi.org/10.1016/S0160-7383(98)00084-X

Rageh, A., Melewar, T.C., Woodside, A. (2013). Using netnography research method to reveal the underlying dimensions of the customer/tourist experience. Qualitative Market Research: An International Journal, 16, 126-149. DOI: https:// doi.org/ 10.1108/13522751311317558

Rittichainuwat, B.N., Chakraborty, G. (2009). Perceived travel risks regarding terrorism and disease: The case of Thailand Tourism Management, 30, 410-418. DOI: https://doi.org/10. 1016/j.tourman.2008.08.001

Sigala, M. (2016). Social media and the co-creation of tourism experiences. W: M. Sotiriadis, D. Gursoy (red.), The Handbook of Managing and Marketing Tourism Experiences (s. 85-111). Bradford: Emerald Group Publishing Limited. DOI: https:/ / doi org/10.1108/978-1-78635-290-320161033

Słownik języka polskiego (2018). Pobrane z: http:/ / sjp.pwn.pl (12.09.2018).

Stamboulis, Y., Skayannis, P. (2003). Innovation strategies and technology for experience - based tourism. Tourism Management, 24, 35-43. DOI: https:/ / doi.org/10.1016/S0261-5177(02)00047-X
Stasiak, A. (2011). Współczesna przestrzeń turystyczna. W: M. Durydiwka, K. Duda-Gromada (red.), Przestrzeń turystyczna. Czynniki, różnorodność, zmiany (s. 39-51). Warszawa: Wyd. Wydziału Geografii i Studiów Regionalnych, Uniwersytet Warszawski.

Stasiak, A. (2013). Nowe przestrzenie o formy turystyki w gospodarce doświadczeń. Turyzm/Tourism, 23 (2), 65-74.

Stasiak, A. (2015). Turystyka kontrowersyjna jako emanacja gospodarki doświadczeń. W: G. Godlewski, M. Zalech (red.), Turystyka kontrowersyjna na wspótczesnym rynku podróży - formy, uwarunkowania, skutki (s. 53-69). Biała Podlaska: Wydawnictwo AWF.

Urry, J. (1990). The tourist gaze: Leisure and travel in contemporary societies. London: Sage Publications.

Waitt, G. (2000). Consuming heritage: Perceived historical authenticity. Annals of Tourism Research, 27, 835-862. DOI: https:/ / doi.org/10.1016/S0160-7383(99)00115-2

Walker, G.J., Hull, R.B., Roggenbuck, J.W. (1998). On-site optimal experiences and their relationship to off-site benefits. Journal of Leisure Research, 30, 453-471. DOI: https:/ / doi.org/10.1080/ 00222216.1998.11949843

Waller, J., Lea, S.E.G. (1999). Seeking the real Spain? Authenticity in motivation. Annals of Tourism Research, 26, 110-129. DOI: https://doi.org/10.1016/S0160-7383(98)00058-9

Weisheng, Ch., Ho, K.L. (2017). Let's go cycling: an analysis of tourists' experience on online user-generated content. International Journal of Tourism Cities, 3, 30-42. DOI: https://doi.org/ 10.1108/IJTC-10-2016-0045

Williams, J.A., Anderson, H.H. (2005). Engaging customers in service creation: A theatre perspective. Journal of Services Marketing, 19, 13-23. DOI: https://doi.org/10.1108/08876040510579352

Zatori A., Beardsley, M. (2017). On-site and memorable tourist experiences: Trending toward value and quality-of-life outcomes. Advances in Hospitality and Leisure, 13, 17-45. DOI https://doi.org/10.1108/S1745-354220170000013003

Artykuł wpłynął: 9 sierpnia $2019 \mathrm{r}$. Zaakceptowano do druku: 21 października $2019 \mathrm{r}$. 